\title{
PENGARUH KETINGGIAN TEMPAT TUMBUH TERHADAP AKTIVITAS ANTIOKSIDAN DAN SITOTOKSIK EKSTRAK RIMPANG LENGKUAS (Alpinia galanga L.)
}

\author{
Subehan Lallo, Ade Christie Lewerissa, Akhmad Rafi'i, Usmar, Ismail, Rosany Tayeb \\ Fakultas Farmasi, Universitas Hasanuddin, Makassar
}

Kata Kunci :

Antioksidan, DPPH, BSLT, Ketinggian Tempat Tumbuh, Rimpang lengkuas, Alpinia galanga $\mathrm{L}$

\section{ABSTRAK}

Rimpang Lengkuas (Alpinia galanga L.) merupakan tanaman yang telah banyak digunakan sebagai rempah dan obat tradisional dalam kehidupan sehari-hari. Tanaman ini mengandung senyawa bioaktif flavonoid yang memiliki efek antioksidan. Penelitian ini dilakukan untuk mengetahui pengaruh ketinggian tempat tumbuh terhadap aktivitas antiokasidan dan toksisitas dari ekstrak rimpang lengkuas (Alpinia galanga L.). Ekstraksi dilakukan dengan cara maserasi sedangkan kadar polifenol dan flavonoid total dilakukan dengan menggunakan metode Folin-ciocalteu dan metode kolorimetri yang dianalisis dengan menggunakan alat spektrofotometer UV-Vis. Uji aktivitas antioksidan dilakukan dengan menggunakan metode DPPH (2,2-Difenil-1-Pikrihidrazil) dan sitotoksisitas dengan menggunakan metode BSLT (Brine Shrimp Lethaly Test). Ekstraksi menggunakan pelarut etil asetat diperoleh rendemen sebesar 2,24\% untuk dataran rendah, 3,51\% dataran sedang dan dataran tinggi sebesar $3,77 \%$. Analisis kadar fenolik dan flavanoid diperoleh berturut turut dari dataran rendah ke tinggi sebesar $6,08 \pm 0,26 \%$ dan $2,25 \pm 0,05 \%, 5,09 \pm 0,14 \%$ dan $1,09 \pm 0,08,5,47 \pm 0,24 \%$ dan $1,16 \pm 0,3 \%$. Aktifitas antioksidan yang tertinggi diperoleh pada dataran rendah diperoleh IC $_{50} 332,48 \mathrm{bpj}$, kemudian pada dataran tinggi dengan IC50 447,14 bpj dan pada dataran sedang diperoleh IC 50 sebesar 518,57 bpj. Uji sitotoksik terhadap ketiga ekstrak menunjukkan hasil $\mathrm{LC}_{50}$ yang tidak terlalu berbeda antara ketiga lokasi tersebut.

\section{PENDAHULUAN}

Kondisi geografis wilayah Indonesia sangat bervariasi dengan iklim tropis dan posisi diantara kedua benua australia dan asia yang merupakan negara kepulauan. Perbedaan lingkungan tersebut mempengaruhi variasi ragam hayati yang dimilikinya yang menjadi sumber bahan alam untuk masyarakatnya dalam keperluan sehari-harinya termasuk bahan makanan ataupun bahan pengobatan berbagai penyakit yang mereka derita. Lingkungan tempat tumbuh yang bervariasi mempengaruhi pertumbuhan tanaman yang berjenis sama termasuk pada kandungan kimia senyawa yang dihasilkannya baik dari segi jumlah maupun dari segi komposisi (1).

\section{Masuk 30-12-2019 \\ Revisi 28-01-2020 \\ Diterima $15-02-2020$}

Korespondensi

Subehan Lallo

subehan@unhas.ac.id

Copyright

(c) 2020 Majalah Farmasi Farmakologi Fakultas

Farmasi · Makassar

Diterbitkan tanggal 16-02-2020

$\mathrm{DO}$

10.20956/mff.v23i3.9404

Dapat Diakses Daring

Pada:

http://journal.unhas.ac.id /index.php/mff
Beberapa penelitian menunjukkan ketinggian tempat merupakan salah satu faktor yang berpengaruh terhadap pertumbuhan suatu tanaman (2). Kandungan fitokimia dari hasil metabolit sekunder seperti flavonoid dari suatu tanaman akan berbeda pada setiap wilayah karena dipengaruhi oleh beberapa faktor lingkungan diantaranya yaitu cahaya, suhu, $\mathrm{pH}$ dan ketinggian tempat tumbuh yang akan berpengaruh terhadap kandungan fitokimia suatu tanaman (3). Disamping hal tersebut, pengolahan bahan baku juga dapat mempengaruhi kandungan kimia yang terekstraksi. Jenis pelarut yang digunakan dapat mempengaruhi senyawa yang terekstraksi dari suatu tanaman (4).

Salah satu tanaman yang umum digunakan bagi masyarakat Indonesia adalah Lengkuas dengan nama ilmiah Alpinia galanga L. suku Zingiberaceae. Tanaman ini merupakan salah satu jenis rempah-rempah indonesia. Rimpang lengkuas (Languatis Rhizoma) telah digunakan sebagai salah satu bahan bumbu masak selama bertahun-tahun. Secara tradisional, lengkuas $(A$. galanga L.) juga sering digunakan sebagai obat sakit perut, karminatif, antijamur, antiinflamasi, antialergi dan antihipoglikemik (5).

Disamping digunakan sebagai obat juga biasanya dimanfaatkan sebagai bahan untuk preventif penyakit yang biasanya dikonsumsi sehari-hari. Bahan yang paling banyak diteliti sebagai obat untuk kuratif dan preventif adalah senyawa antioksidan. Bahan ini merupakan senyawa yang dapat menunda atau mencegah terjadinya reaksi oksidasi dari radikal bebas dalam oksidasi lipid (6). Berbagai sumber dari radikal bebas dihasilkan melalui polutan lingkungan, asap rokok, asap knalpot mobil, radiasi, polutan udara dan pestisida. Sumber-sumber tersebut tidak bisa dipisahkan dalam kehidupan kita sehari-hari sehingga sangat rentang untuk selalu terpapar (7).

Radikal bebas yang terdapat didalam tubuh bersifat sangat reaktif dan akan berinteraksi secara destruktif melalui reaksi oksidasi dengan bagian tubuh maupun sel-sel yang terbentuk dari protein, lipid, DNA, karbohidrat dan membran sehingga menimbulkan stres oksidatif yang dapat memicu berbagai jenis penyakit seperti jantung koroner, kanker dan penuaan dini. Salah satu cara untuk menghadapi hal tersebut dengan antioksidan (8). Secara alami di dalam tubuh manusia sudah terdapat senyawa antioksidan untuk melawan radikal bebas yang berlebih, Namun perubahan pola hidup termasuk pola makan yang tidak benar disertai dengan bertambahnya usia menyebabkan produksi antioksidan dalam tubuh semakin berkurang. Dalam kondisi tersebut, tubuh membutuhkan tambahan antioksidan dari luar (9). 
Identifikasi kandungan senyawa dalam lengkuas menunjukkan hasil yang positif terhadap senyawa flavanoid (10). Senyawa ini merupakan senyawa fenolik yang sangat bermanfaat dalam makanan karena bersifat antioksidan. Lengkuas (Alpinia galanga L.) mengandung flavonoid jenis galangin, kamferol dan kuersetin, ketiga senyawa flavonoid ini memiliki efek antioksidan yang baik (11). Berdasarkan hal tersebut, maka diteliti pengaruh ketinggian tempat tumbuh terhadap aktivitas antioksidan dan toksisitas dari ekstrak rimpang lengkuas (Alpinia galanga L.).

\section{METODE PENELITIAN}

\section{Alat dan Bahan}

Alat-alat yang digunakan dalam penelitian ini adalah alat gelas (Pyrex®), ayakan, blender, cawan porselen, eksikator,

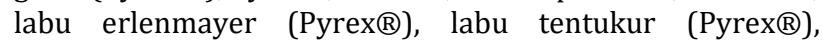
micropipet (Thermo Scientific $($ ), oven simplisia (Memmert $\AA$ ), rotary evaporator (Buchi $\AA$ ), spektrofotometer UV-Vis (Shimadzu $®$ ), tabung reaksi (Iwaki ${ }^{\circledR}$ ), timbangan analitik (Sartorius ${ }^{\circledR}$ ) dan water bath (memmert®).

Bahan yang digunakan dalam penelitian ini yaitu alumunium klordia $\left(\mathrm{AlCl}_{3}\right)$, asam galat, (Merck), air suling (Water one), DPPH (2,2-diphenyl-1-picrylhydrazin), etil asetat, Besi (III) klorida $\left(\mathrm{FeCl}_{3}\right)$, Folin-Ciocalteu (Merck), HCL pekat, kuersetin, magnesium, metanol p.a, $\mathrm{NaOH}$, rimpang lengkuas (Alpinia galanga L.) dan vitamin C.

\section{Prosedur Kerja}

\section{Penyiapan Sampel Penelitian}

Sampel lengkuas (Alpinia galanga L.) diambil dari 3 lokasi dengan ketinggian berbeda yaitu dataran rendah $(<250$ mdpl) yang diperoleh dari kelurahan Balandai, kecamatan Bara, kota Palopo dengan ketinggian 20 mdpl. kemudian dataran sedang (250-750 mdpl) diperoleh lari kelurahan Kambo, kecamatan Mungkajang, kota Palopo dengan ketinggian $425 \mathrm{mdpl}$ dan dataran tinggi (>750 mdpl) diperoleh dari kelurahan Palawa, Kecamatan Sesean, kota Rantepao dengan ketinggian 1093 mdpl.

Sampel lengkuas (Alpinia galanga L.) yang telah diperoleh disortasi basah kemudian dicuci dengan menggunakan air mengalir kemudian dirajang kecil-kecil dan dikeringkan didalam oven simplisia dengan suhu $40^{\circ} \mathrm{C}$ selama 3 hari. Simplisia yang telah diperoleh kemudian diserbukan dengan menggunakan blender dan diayak dengan ayakan mesh 20 ukuran $850 \mu \mathrm{m}$.

\section{Penyiapan Ekstrak}

Serbuk lengkuas (Alpinia galanga L.) masing-masing sebanyak $400 \mathrm{~g}$ dimaserasi menggunakan etil asetat dengan perbandingan 1:10 selama $3 \times 24$ jam. Setelah itu disaring dengan menggunakan kertas saring untuk memisahkan residu dan filtratnya. Selanjutnya filtratnya dievaporasi untuk menguapkan pelarutnya, sehingga diperoleh ekstrak kental dari rimpang lengkuas (Alpinia galanga $\mathrm{L}$ ).

\section{Penyiapan Larutan Stok}

\section{Larutan Stok Sampel}

Larutan stok pembanding asam galat dibuat dengan cara timbang asam galat sebanyak $10 \mathrm{mg}$, kemudian dilarutkan dengan metanol p.a dalam labu tentukur $10 \mathrm{~mL}$ dan dicukupkan volumenya hingga garis tanda sehingga diperoleh larutan stok dengan konsentrasi (1000 bpj).

\section{Baku Pembanding Asam Galat}

Larutan stok pembanding asam galat dibuat dengan cara timbang asam galat sebanyak $10 \mathrm{mg}$, kemudian dilarutkan dengan metanol p.a dalam labu tentukur $10 \mathrm{~mL}$ dan dicukupkan volumenya hingga garis tanda sehingga diperoleh larutan stok dengan konsentrasi (1000 bpj).

\section{Baku Pembanding Kuersetin}

Larutan stok pembanding kuersetin dibuat dengan cara timbang kuersetin sebanyak $10 \mathrm{mg}$, kemudian dilarutkan dengan metanol p.a dalam labu tentukur $10 \mathrm{~mL}$ dan dicukupkan volumenya hingga garis tanda sehingga diperoleh larutan stok dengan konsentrasi (1000 bpj).

\section{Baku Pembanding Kuersetin}

Untuk larutan stok pembanding (Vitamin C) dibuat dengan cara ditimbang vitamin C sebanyak $10 \mathrm{mg}$, kemudian dilarutkan dengan mengguanakan p.a dalam labu tentukur $10 \mathrm{ml}$, kemudian dipipet $1 \mathrm{~mL}$ dan dimasukan kedalam labu tentukur $10 \mathrm{~mL}$ dan dicukupkan volumenya hingga batas tanda dan diperoleh larutan stok dengan konsentrasi 100 bpj.

\section{Uji Kualitatif}

\section{Senyawa Fenol}

Ekstrak lengkuas masing-masing sebanyak $2 \mathrm{~mL}$ dimasukan kedalam tabung reaksi kemudian ditambahkan 2-3 tetes $\mathrm{FeCl} 3$. Hasil positif adanya senyawa fenolik ditandai dengan terjadinya perubahan warna larutan menjadi hijau, merah, ungu, biru atau hitam yang kuat menunjukan adanya senyawa fenolik dalam sampel.

\section{Senyawa Flavonoid}

Ekstrak lengkuas masing-masing sebanyak $2 \mathrm{~mL}$ lengkuas dimasukan kedalam tabung reaksi kemudian ditambahkan serbuk Mg dan 3 tetes $\mathrm{HCl}$ pekat kemudian dihomogenkan dan diamati perubahan warnanya. Hasil positif flavanoid di tandai dengan larutan berwarna merah, kuning dan jingga.

\section{Uji Kuantitatif}

\section{Senyawa Fenol}

\section{Penentuan Panjang Gelombang}

Larutan stok baku pembanding yang telah dibuat. Diukur panjang gelombang maksimumnya. Serapan diukur dengan spektrofotometer UV-Vis yang telah diatur panjang gelombangnya dari $400-800 \mathrm{~nm}$ hingga diperoleh panjang gelombang maksimal 715,5 $\mathrm{nm}$

\section{Pembuatan Kurva Baku}

Larutan stok pembanding yang telah dibuat sebelumnya diencerkan kembali menjadi 100 bpj dengan mencuplik 1 mL larutan stok kemudian diencerkan dengan metanol p.a dalam labu tentukur $10 \mathrm{~mL}$. Dibuat pengenceran secara kuantitatif dengan seri pengenceran $2 ; 4 ; 6$; 8 ; dan 10 bpj dalam labu tentukur $5 \mathrm{~mL}$. Kemudian masingmasing ditambahkan dengan 2,5 mL Folin Ciocalteu LP (7,5\% dalam air), diamkan selama 8 menit, $2 \mathrm{~mL} \mathrm{NaOH}$ $1 \%$, dan dicukupkan dengan aquades sampai batas tanda. Setelah itu dihomogenkan dan diinkubasi selama 60 menit pada suhu ruang kemudian dikukur absorbansinya dengan spektrofotometer UV-Vis.

3. Penentuan Kadar Fenolik Total Sampel

Pengukuran sampel dilakukan dengan cara diambil 0,3 mL larutan stok sampel dan dimasukkan ke dalam labu tentukur berukuran $5 \mathrm{~mL}$, lalu ditambahkan 2,5 reagen Folin-Ciocalteu dan $2 \mathrm{~mL} \mathrm{NaOH} \mathrm{1 \% .} \mathrm{Replikasi} \mathrm{dilakukan}$ sebanyak 3 kali. Larutan uji diinkubasi selama 30 menit lalu diukur absorbansinya dengan spektrofotometer UVVis pada panjang gelombang $715,5 \mathrm{~nm}$. 


\section{Senyawa Flavonoid}

1. Penentuan Panjang Gelombang

Larutan stok baku pembanding yang telah dibuat. Diukur panjang gelombang maksimumnya. Serapan diukur dengan spektrofotometer UV-Vis yang telah diatur panjang gelombangnya dari 400-800 $\mathrm{nm}$ hingga diperoleh panjang gelombang maksimal 429,5 nm

2. Pembuatan Kurva Baku

Kurva baku dibuat dengan pengenceran secara kuantitatif dari larutan stok yang telah dibuat dan jika perlu bertahap dengan metanol p.a hingga kadar $2 ; 4 ; 6$; 8; dan 10 bpj didalam labu tentukur 5 mL. Kemudian masing-masing ditambahkan dengan $1,5 \mathrm{~mL}$ etanol p.a; $0,1 \mathrm{~mL}$ aluminium klorida $10 \% ; 0,1 \mathrm{~mL}$ natrium asetat 1 $\mathrm{M}$ dan dicukupkan dengan aquades sampai batas tanda. Setelah itu dihomogenkan dan diinkubasi selama 30 menit pada suhu ruang.

\section{Penentuan Kadar Fenolik Total Sampel}

Masing-masing sampel dicuplik sebanyak 0,5 mL kedalam labu tentukur $5 \mathrm{~mL}$, kemudian ditambahkan 1,5 $\mathrm{mL}$ etanol p.a; 0,1 mL aluminium klorida $10 \%$; 0,1 mL natrium asetat $1 \mathrm{M}$ dan dicukupkan dengan aquades sampai batas tanda. Setelah itu dihomogenkan dan diinkubasi selama 30 menit pada suhu ruang.

Masing-masing ekstrak rimpang lengkuas diukur menggunakan spektrofotometer UV-Vis pada panjang gelombang serapan maksimum kuersetin yaitu 429,5 nm. Dilakukan pengukuran blangko terlebih dahulu, kemudian masing-masing larutan uji di ukur panjang gelombang serapan maksimumnya. Hitung kadar flavonoid dengan membandingkan konsentrasi antara larutan uji dengan larutan pembanding dalam $\% \mathrm{~b} / \mathrm{b}$.

\section{Uji Aktivitas Antioksidan Menggunakan Metode DPPH}

\section{Pembuatan Larutan DPPH 0,4 mM}

Larutan DPPH 0,4 mM dibuat dengan cara ditimbang $15.8 \mathrm{mg}$ DPPH kemudian dilarutkan dengan metanol pro analisis hingga volume $100 \mathrm{~mL}$ dalam labu tentukur.

\section{Pembuatan Larutan DPPH 0,4 mM}

Larutan stok masing-masing sampel dipipet sebanyak 500, $1000,1500,2000$ dan $2500 \mu \mathrm{L}$ dan dimasukan kedalam labu tentukur $5 \mathrm{~mL}$ untuk membuat seri pengenceran 100, 200, 300, 400 dan 500 bpj. Tambahkan $1 \mathrm{~mL}$ larutan DPPH 0,4 Mm kemudian dicukupkan dengan metanol p.a hingga batas tanda pada labu tentukur dan dihomogenkan. Masing-masing seri pengenceran kemudian diukur absorbansinya pada panjang gelombang $517 \mathrm{~nm}$. Data hasil pengukuran absorbansi kemudian dianalisi presentase aktivitas antioksidannya dengan menggunakan persamaan berikut :

$\%$ Inhibisi $=($ A.blanko-A.sampel $) /($ A.Blanko $) \times 100 \%$

\section{Uji toksisitas}

Larutan stok masing-masing sampel dipipet sebanyak 500, $1000,1500,2000$ dan $2500 \mu \mathrm{L}$ dan dimasukan kedalam labu tentukur $5 \mathrm{~mL}$ untuk membuat seri pengenceran 100, 200, 300, 400 dan 500 bpj. Tambahkan 1 mL larutan DPPH 0,4 Mm kemudian dicukupkan dengan metanol p.a hingga batas tanda pada labu tentukur dan dihomogenkan. Masing-masing seri pengenceran kemudian diukur absorbansinya pada panjang gelombang $517 \mathrm{~nm}$. Data hasil pengukuran absorbansi kemudian dianalisi presentase aktivitas antioksidannya dengan menggunakan persamaan berikut :

\section{Penyiapan Larva Artemia salina L.}

Penyiapan larva dilakukan dengan mengambil telur larva udang (Artemia salina L.) sebanyak $50 \mathrm{mg}$. Penetasan dilakukan dengan cara merendam telur tersebut dalam air garam sebanyak $400 \mathrm{~mL}$ dan diberi penerangan dengan lampu pijar serta diaerasi selama 48 jam. Air garam dibuat dengan cara melarutkan 30 g garam dalam $1 \mathrm{~L}$ air kemudian disaring

\section{Penyiapan Larutan Stok}

Larutan uji dibuat dengan melarutkan ekstrak ke dalam air garam dengan konsentrasi 1000 ppm, 100 ppm, 10 ppm, dan 1 ppm. Masing-masing konsentrasi dimasukkan ke dalam labu tentukur $25 \mathrm{~mL}$.

\section{Uji BSLT}

Pengujian dilakukan dengan memasukkan 10 ekor larva Artemia salina (L). berumur 48 jam ke dalam vial volume 5 $\mathrm{mL}$ yang telah berisi larutan ekstrak dan air garam. Pengamatan dilakukan setelah 24 jam, kemudian dihitung larva udang (Artemia salina L.) yang mati. Untuk mengetahui nilai $\mathrm{LC}_{50}$ menggunakan metode analisis probit.

Pengujian efek toksik dihitung dengan menentukan nilai $\mathrm{LC}_{50}$ menggunakan analisis probit. Untuk mendapatkan nilai $\mathrm{LC}_{50}$, terlebih dahulu menghitung persentase kematian hewan uji setelah 24 jam dengan cara: \% kematian larva = (Jumlah larva yang mati)/(Jumlah larva uji) x 100\%.

Apabila pada kontrol ada larva yang mati, maka \% kematian ditentukan dengan rumus: \% kematian larva $=($ Jumlah larva yang mati-jumlah larva kontrol yang mati)/(Jumlah larva uji) $\mathrm{x} 100 \%$.

Dengan mengetahui persentase kematian dari larva uji, selanjutnya dicari angka probit melalui tabel dan dibuat grafik dengan logaritma konsentrasi sebagai sumbu $\mathrm{x}$ terhadap persentase kematian dalam satuan probit sebagai sumbu y. Nilai LC50 merupakan konsentrasi dimana zat menyebabkan kematian $50 \%$ yang diperoleh dengan memakai persamaan regresi linier $y=a+b x$, atau $p=a+b$ (Log LC).

\section{HASIL DAN PEMBAHASAN}

Penelitiaan ini dilakukan untuk melihat pengaruh ketinggian tempat tumbuh terhadap aktivitas antioksidan dari ekstrak rimpang lengkuas (Alpinia galanga L.). Pada penelitian ini sampel yang digunakan adalah rimpang lengkuas (Alpinia galanga L.) yang diperoleh dari 3 daerah dengan tingkat ketinggian tempat tumbuh berbeda. Sampel yang pertama dataran rendah $(<250 \mathrm{mdpl})$ yang diperoleh dari Kelurahan Balandai, Kecamatan Bara, Kota Palopo dengan ketinggian 20 mdpl. Kemudian sampel kedua dataran sedang (250-750 mdpl) diperoleh dari Kelurahan Kombo, Kecamatan Mungkajang, Kota Palopo dengan ketinggian $425 \mathrm{mdpl}$ dan sampel ketiga yaitu dataran tinggi ( $>750 \mathrm{mdpl}$ ) diperoleh dari Kelurahan Palawa, Kecamatan Sesean, Kota Rantepao dengan ketinggian 1093 mdpl.

\begin{tabular}{cccc} 
Tabel 1. Data Hasil Persen Rendemen & & \\
\hline Sampel & $\begin{array}{c}\text { Bobot } \\
\text { Simplisia } \\
\text { (gram) }\end{array}$ & $\begin{array}{c}\text { Bobot } \\
\text { Ekstrak } \\
\text { (gram) }\end{array}$ & $\begin{array}{c}\text { Rendemen } \\
\text { (\%) }\end{array}$ \\
\hline Dataran Rendah & 400 & 8,97 & 2,24 \\
Dataran Sedang & 400 & 14,02 & 3,51 \\
Dataran Tinggi & 400 & 15.2 & 3,77 \\
\hline
\end{tabular}


Setelah diperoleh sampel kemudian dikeringkan dan diekstraksi dengan cari meserasi dengan menggunakan pelarut etil asetat. Menurut penelitian yang dilakukan oleh Herni dan Shofia (10), kandungan senyawa fenolat tertinggi terkandung pada ekstrak etil asetat. Ekstrak cair yang diperoleh masih mengandung banyak pelarut sehingga diuapkan dengan menggunakan alat rotary evaporator sehingga diperoleh ekstrak kental. Ekstrak kental kemudian dihitung persen rendemennya untuk mengetahui banyaknya ekstrak yang dihasilkan. Diperoleh data persen rendemen dari ketiga sampel ekstrak berturut-turut dataran rendah $2,2 \%$, dataran sedang 3,5\% dan dataran tinggi 3,8\% (tabel 1). Dari hasil yang diperoleh terdapat perbedaan hasil rendemen yang menunjukan bahwa ketinggian tempat tumbuh berpengaruh terhadap jumlah ekstrak yang dihasilkan. Semakin tinggi tempat tumbuh maka semakin tinggi hasil persen rendemen ekstrak hal ini disebabkan karena salah satu senyawa yang yang terdapat pada sampel yaitu minyak atsiri. Semakin tinggi dataran tempat tumbuh maka akan semakin banyak kandungan minyak atsiri dalam sampel.

Pengujian kualitatif senyawa fenolik dan flavonoid dilakukan dengan menggunakan pereaksi. Pengujian ini dilakukan untuk mengetahui apakah terdapat senyawa fenolik dan flavonoid pada sampel dengan melihat perubahan warna. Pada pengujian fenolik digunakan pereaksi $\mathrm{FeCl}_{3}$ dan diperoleh hasil bahwa masing-masing ekstrak postif mengandung senyawa fenol. Senyawa fenol pada ekstrak akan membentuk kompleks dengan ion besi $\mathrm{Fe}^{3+}$ sehingga terbentuknya warna biru kehitaman pad pengujian yang dilakukan. Pada pengujian kualitatif senyawa flavonoid dilakukan penambahan logam $\mathrm{Mg}$ dan $\mathrm{HCl}$ yang akan membentuk garam flavilium berwarna merah atau jingga (12).

Pengukuran kadar fenolik total ditentukan dengan menggunakan metode Folin-ciocalteu yang dianalasis dengan menggunakan spektrofotomer UV-Vis dengan baku pembanding yang digunakan yaitu asam galat. Metode ini adalah metode yang umum digunakan untuk penentuak kadar fenolik total karena merupakan metode yang tergolong sederhana yang dinyatakan sebagai masa ekuivalen asam galat tiap mg sampel (13).

\begin{tabular}{ccc} 
Tabel 2. Data Kurva Baku Asam Galat \\
\hline Sampel & Konsentrasi & Absorbansi (WL 715,5) \\
\hline Blanko & 0 & 0 \\
Asam Galat 1 & 2 & 0,179 \\
Asam Galat 2 & 4 & 0,409 \\
Asam Galat 3 & 6 & 0,558 \\
Asam Galat 4 & 8 & 0,686 \\
Asam Galat 5 & 10 & 0,887 \\
\hline
\end{tabular}

Pengukuran kadar fenol total dilakukan pada panjang gelombang $715,5 \mathrm{~nm}$. Kurva baku yang dibuat dengan konsentrasi 2, 4, 6, 8 dan 10 bpj memperoleh persamaan garis regresi linear $\mathrm{y}=0,0847 \mathrm{x}+0,0359$ dengan nilai koefisien korelasi 0,9936 (tabel 2, gambar 1). Diperoleh kadar fenol dari ketiga sampel yaitu dataran rendah $6,08 \pm 0,24 \%$, dataran sedang 5,09 $\pm 0,14 \%$ dan dataran tinggi yaitu $5,47 \pm 0,24 \%$ (gambar 3 ). Dapat dilihat dari hasil yang diperoleh bahawa sampel dataran rendah memiliki kandungan polifenol terbanyak dibandingkan dengan dataran sedang dan dataran tinggi. Hal ini kemungkinan besar disebabkan karena pada dataran rendah intensitas paparan sinar matahari lebih banyak bila dibandingkan dengan kedua daerah lainnya sehingga proses fotosintesis yang dilakukan lebih maksimal dibandingkan dengan kedua dataran yang lainnya. Pada sampel dataran sedang memiliki persen kadar fenol lebih sedikit dari dataran tinggi hal ini disebabkan karena selain ketinggian tempat tumbuh pengaruh lingkungan tumbuh juga mempengaruhi kandungan senyawa didalam tanaman. Sampel dataran sedang tumbuh diantara pohon-pohon yang cukup besar dan rindang sehingga cahaya matahari yang diperoleh tidak begitu maksimal hal ini bisa menjadi faktor pengaruh dari hasil yang diperoleh.

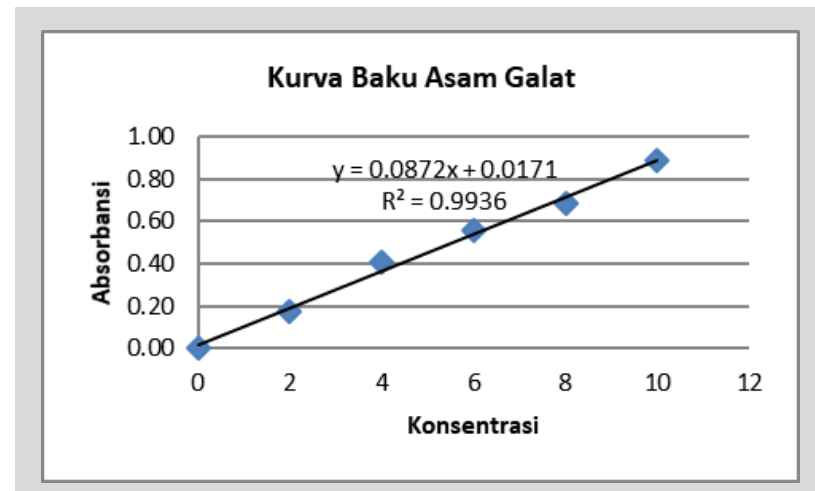

Gambar 1. Hubungan konsentrasi dan absorbansi larutan asam galat.

Tabel 3. Hasil Pengukuran Kadar Polifenol Sampel dihitung sebagai asam gallat

\begin{tabular}{lcccccc}
\hline Sampel & Konsentrasi & Absorbansi & Nilai X & $\begin{array}{c}\% \\
\text { Kadar }\end{array}$ & $\begin{array}{c}\text { Rata- } \\
\text { rata }\end{array}$ & SD \\
\hline $\begin{array}{l}\text { Dataran } \\
\text { tinggi 1 }\end{array}$ & 5,29 & 0,48 & 5,35 & 5,35 & & \\
$\begin{array}{l}\text { Dataran } \\
\text { tinggi 2 }\end{array}$ & 5,70 & 0,52 & 5,74 & 5,74 & 5,47 & 0,24 \\
$\begin{array}{l}\text { Dataran } \\
\text { tinggi 3 }\end{array}$ & 5,24 & 0,48 & 5,31 & 5,31 & & \\
\hline $\begin{array}{c}\text { Dataran } \\
\text { sedang 1 }\end{array}$ & 4,87 & 0,45 & 4,94 & 4,94 & & \\
$\begin{array}{l}\text { Dataran } \\
\text { sedang 2 }\end{array}$ & 5,17 & 0,47 & 5,23 & 5,23 & 5,09 & 0,14 \\
$\begin{array}{l}\text { Dataran } \\
\text { sedang 3 }\end{array}$ & 5,03 & 0,46 & 5,10 & 5,10 & & \\
\hline $\begin{array}{l}\text { Dataran } \\
\text { rendah 1 }\end{array}$ & 6,01 & 0,55 & 6,05 & 6,05 & & \\
$\begin{array}{l}\text { Dataran } \\
\text { rendah 2 }\end{array}$ & 6,31 & 0,57 & 6,35 & 6,35 & 6,08 & 0,25 \\
$\begin{array}{l}\text { Dataran } \\
\text { rendah 3 }\end{array}$ & 5,79 & 0,53 & 5,85 & 6,85 & & \\
\hline & & & & & & \\
\hline
\end{tabular}

Pengukuran kadar flavonoid total ditentukan dengan menggunakan metode kolorimetri yang dianalasis dengan menggunakan spektrofotometer UV-Vis dengan baku pembanding yang digunakan yaitu kuersetin. Kuersetin merupakan baku pembanding untuk senyawa flavonoid yang memiliki banyak bioaktifitas. Penentuan kadar flavonoid total dilakukan dengan menggunakan metode kolorimetri dengan penambahan alumunium klorida dan natrium asetat. Dalam penentuan kadar flavonoid total variasi kurva baku kuersetin dibuat dengan beberapa seri pengenceran yaitu 2 , 4, 6, 8 dan 10 bpj sehingga diperoleh persamaan garis linear $\mathrm{y}=0,0972 \mathrm{x}-0,0106$ dengan nilai koefisien korelasi yaitu 0,9981 (tabel 4, gambar 2). Dari persamaan kurva baku yang diperoleh, maka kadar flavonoid total yang dihitung dengan kuersetin sebagai senyawa pembanding dan berdasarkan nilai absorbansi ekstrak maka diperoleh kadar flavonoid total yaitu pada dataran rendah $2,15 \pm 0,05 \%$, dataran sedang $1,09 \pm 0,08 \%$ dan dataran tinggi $1,16 \pm 0,03 \%$ (tabel 5). Dari hasil yang diperoleh maka dapat dilihat bahwa kadar flavonoid tertinggi terdapat pada sampel dataran rendah hal ini berbanding lurus dengan hasil yang diperoleh pada kadar 
total kandungan senyawa fenol pada ketiga sampel. Flavonoid merupakan salah satu bagian dari senyawa fenol.

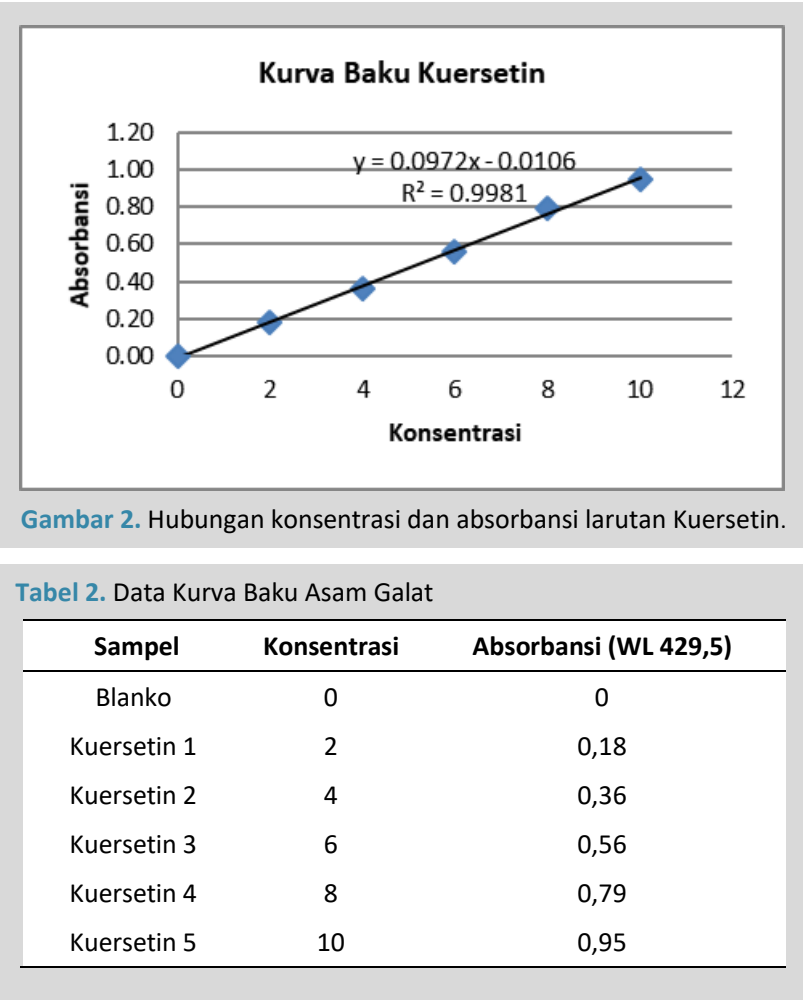

Metode DPPH merupakan metode yang dapat mengukur aktivitas total antioksidan baik dalam pelarut polar maupun nonpolar. Metode ini mengukur semua komponen antioksidan, baik yang larut dalam lemak maupun yang larut dalam air (14). Baku pembanding yang digunakan dalam penelitian ini yaitu asam askorbat (Vitamin C). Hasil yang diperoleh dari uji aktivitas antioksidan dengan menggunakan metode DPPH pada sampel rimpang lengkuas dengan $\mathrm{IC}_{50}$ berdasarkan ketinggian tempat tumbuh yaitu dataran rendah $332,48 \mathrm{bpj}$, dataran sedang $518,57 \mathrm{bpj}$, dan dataran tinggi 447,14 bpj (tabel 6). Sampel dari ketiga tempat tersebut memiliki aktivitas antiokasidan yang lemah. Hasil ini sama dengan penelitian yang dilaksanakan oleh Ujala (15) dan Kasertsart (16) bahwa rimpang lengkuas memiliki aktivitas antioksidan yang lemah.

Tabel 5. Hasil Pengukuran Kadar Flavonoid Sampel dihitung sebagai kuersetin

\begin{tabular}{cccccccc}
\hline Sampel & Konsentrasi & Absorbansi & Nilai X & Kadar & $\begin{array}{c}\text { Rata- } \\
\text { rata }\end{array}$ & SD \\
\hline $\begin{array}{c}\text { Dataran } \\
\text { tinggi 1 }\end{array}$ & 1,13 & 0,10 & 1,13 & 1,13 & & \\
$\begin{array}{c}\text { Dataran } \\
\text { tinggi 2 }\end{array}$ & 1,16 & 0,10 & 1,17 & 1,17 & 1,16 & 0,03 \\
$\begin{array}{c}\text { Dataran } \\
\text { tinggi 3 }\end{array}$ & 1,19 & 0,11 & 1,19 & 1,19 & & \\
\hline $\begin{array}{c}\text { Dataran } \\
\text { sedang 1 }\end{array}$ & 1,00 & 0,09 & 1,00 & 1,00 & & \\
$\begin{array}{c}\text { Dataran } \\
\text { sedang 2 }\end{array}$ & 1,09 & 0,10 & 1,09 & 1,09 & 1,09 & 0,08 \\
$\begin{array}{c}\text { Dataran } \\
\text { sedang 3 }\end{array}$ & 1,17 & 0,10 & 1,17 & 1,17 & & \\
\hline $\begin{array}{c}\text { Dataran } \\
\text { rendah 1 }\end{array}$ & 2,11 & 0,19 & 2,10 & 2,10 & & \\
$\begin{array}{c}\text { Dataran } \\
\text { rendah 2 }\end{array}$ & 2,21 & 0,20 & 2,21 & 2,21 & 2,15 & 0,05 \\
$\begin{array}{l}\text { Dataran } \\
\text { rendah 3 }\end{array}$ & 2,15 & 0,20 & 2,15 & 2,15 & & \\
\hline
\end{tabular}

Aktivitas antioksidan pada suatu tanaman bergantung pada kandungan senyawa tanaman tersebut. Senyawa flavonoid pada rimpang lengkuas diduga memiliki aktifitas sebagai antioksidan. Jika dilihat dari hasil analisis kualitatif menunjukan bahwa ekstrak etil asetat rimpang lengkuas dari ketiga sampel mengandung senyawa fenol dan flavonoid. Hal ini didukung dengan hasil uji kuantitatif yang dianalisis dengan menggunakan spektrofotometri UV-Vis dan diperoleh hasil persen kadar fenol dan flavonoid pada sampel. Semakin tinggi ketinggian tempat tumbuh menunjukan aktivitas antioksidan yang semakin lemah. Pengaruh ketinggian tempat terhadap tanaman berkaitan erat dengan faktor lingkungan, misalnya suhu. Suhu udara pada dataran rendah yang lebih tinggi menyebabkan kapasitas uap air meningkat, sehingga kelembaban udara relatif berkurang terutama disiang hari. Selain itu juga faktor intensitas cahaya matahari, rendahnya nilai intensitas cahaya matahari dapat disebabkan karena adanya naungan seperti awan, pohon atau bentuk naungan lainnya (17). Selain itu pengaruh umur panen sampel juga dapat mempengaruhi kandungan senyawa pada sampel. Umur panen paling baik untuk sampel rimpang yang mengandung minyak atsiri yaitu 7-10 bulan (18). Pada penelitian ini tidak dapat dipastikan umur dari sampel karena meskipun sampel merupakan tanaman yang ditanaman oleh warga namun tidak dapat dipastikan umur sampel yang digunakan. Sedangkan hasil uji sitotoksisitas dengan metode uji BSLT diperoleh hasil bahwa ekstrak lengkuas yang ditanam baik dari dataran rendah, sedang maupun tinggi memiliki nilai $\mathrm{LC}_{50}$ tidak berbeda signifikan yaitu dengan nilai 11,37 bpj, 10,71 bpj, dan 12,4 bpj (tabel 6). Kurangnya pengaruh ini kemungkinan disebabkan karena bagian yang diambil adalah bagian rimpang (berada di dalam tanah) yang terlindung dari paparan sinar matahari dan cuaca sekitarnya. Adapun variasi nilai yang muncul kemungkinan disebabkan oleh kondisi tanah tempat tumbuh lengkuas tersebut. Rendahnya nilai $\mathrm{LC}_{50}$ tersebut bisa disebabkan karena tidak diketahuinya konsentrasi pelarut sisa dalam ekstrak yang dapat mempengaruhi hasil penelitian.

\begin{tabular}{|c|c|c|c|c|c|c|c|}
\hline No & Variabel & \multicolumn{2}{|c|}{ Dataran Rendah } & \multicolumn{2}{|c|}{ Dataran Sedang } & \multicolumn{2}{|c|}{$\begin{array}{c}\text { Dataran } \\
\text { Tinggi }\end{array}$} \\
\hline 1 & \begin{tabular}{|l|} 
Ketinggian \\
tempat \\
tumbuh \\
\end{tabular} & \multicolumn{2}{|c|}{$20 \mathrm{mdpl}$} & \multicolumn{2}{|c|}{$425 \mathrm{mdpl}$} & \multicolumn{2}{|c|}{1093 mdpl } \\
\hline 2 & \begin{tabular}{|l|} 
Persen \\
rendemen
\end{tabular} & \multicolumn{2}{|c|}{$2,2 \%$} & \multicolumn{2}{|c|}{$3,5 \%$} & \multicolumn{2}{|c|}{$3,8 \%$} \\
\hline \multirow[t]{2}{*}{3} & \multirow[t]{2}{*}{ Uji Kualitatif } & Fenol & $\begin{array}{c}\text { Flavo- } \\
\text { noid }\end{array}$ & Fenol & $\begin{array}{l}\text { Flavo- } \\
\text { noid }\end{array}$ & Fenol & $\begin{array}{c}\text { Flavo- } \\
\text { noid }\end{array}$ \\
\hline & & + & + & + & + & + & + \\
\hline 4 & \begin{tabular}{|l|} 
Uji \\
Kuantitatif
\end{tabular} & $\begin{array}{l}6,08 \pm \\
0,24 \%\end{array}$ & $\begin{array}{l}2,15 \pm \\
0,05 \%\end{array}$ & $\begin{array}{l}5,09 \pm \\
0,14 \%\end{array}$ & $\begin{array}{l}1,09 \pm \\
0,08 \%\end{array}$ & \begin{tabular}{|l|}
$5,47 \pm$ \\
$0,24 \%$
\end{tabular} & $\begin{array}{c}1,16 \pm \\
0,03\end{array}$ \\
\hline 5 & $\begin{array}{l}\text { Antioksidan } \\
\left(\mathrm{I}_{50}\right)\end{array}$ & \multicolumn{2}{|c|}{332,48 bpj } & \multicolumn{2}{|c|}{$518,57 \mathrm{bpj}$} & \multicolumn{2}{|c|}{$447,14 \mathrm{bpj}$} \\
\hline 6 & $\begin{array}{l}\text { Sitotoksisitas } \\
\left(\mathrm{LC}_{50}\right)\end{array}$ & \multicolumn{2}{|c|}{ 11,37 bpj } & \multicolumn{2}{|c|}{ 10,71 bpj } & \multicolumn{2}{|c|}{$12,4 \mathrm{bpj}$} \\
\hline
\end{tabular}

\section{KESIMPULAN}

Dari hasil penelitian uji aktivitas antiokisdian ekstrak etilasetat rimpang lengkuas (Alpinia galanga L.) dengan menggunakan metode DPPH (2,2-diphenil-1-pikrihidrazil) dapat disimpulkan diperoleh persen rendemen dari ketiga ekstrak yaitu dataran rendah 2,24\%, dataran sedang 3,51\% dan dataran tinggi 3,77\%. kandungan senyawa Polifenol pada masing-masing sampel yaitu dataran tinggi $5,47 \pm 0,24 \%$, dataran sedang $5.09 \pm 0,14 \%$ dan dataran rendah $6.08 \pm 0,25 \%$ serta kandungan senyawa flavonoid pada masing-masing sampel yaitu dataran tinggi $1,16 \pm 0,03$, dataran sedang 1,09 $\pm 0,08$ dan dataran rendah 2,15 $\pm 0,05$. Dan Aktivitas antioksidan atau IC50 dari sampel masingmasing sampel yaitu sampel dataran tinggi 447,14 bpj, 
dataran sedang 518,57 bpj dan dataran rendah 332,48 bpj. Sedangkan hasil uji sitotoksiknya menunjukan pengaruh yang tidak signifikan dari ketiga lokasi tersebut.

Dari hasil yang diperoleh terdapat perbedaan pada setiap sampel namun kurang signifikan sehingga dapat dikatakan bahwa ketinggian tempat tumbuh kurang berpengaruh terhadap aktivitas kandungan senyawa dari tanaman rimpang lengkuas (Alpinia galanga L.).

\section{DAFTAR PUSTAKA}

1. Udin M. Environmental Factors on Secondary Metabolism of Medicinal Plants. Acta Scientific Pharmaceutical Science. 2019; 3(8), 34-46.

2. Laily AN, Suranto S. Characteristics of Carica Pubscens of Dieng Plateu, Central Java According to its Morphology, Antioxidant, and Protein pattern. Nusantara Biscience. 2012; 4(1), 16-21

3. Sholekah F. Perbedaan Ketinggian Tempat Tumbuh Terhadap Kandungan Flavonoid dan Beta Karoten Buah Karika (Carica pubescens) Daerah Dieng Wonosobo. Fakultas MIPA, Universitas Negeri Yogyakarta. 2017; 75-82

4. Subehan, Rifai Y, Mufidah. The Characterization and Anti-osteoporotic Activity of Sappan Lignum (Caesalpinia sappan L.) Extracts. International Journal of Phytomedicine. 2013, 5, 7-13.

5. Darmawan DA. Efektivitas Etanol Lengkuas Putih (Alpinia galangan L.Wild) Dalam Menghambat Pertumbuhan Candida albicans Secara In vitro. Fakultas Kedokteran Brawijaya; 2013

6. Yuslianti ER. Faramayuda F, Juliastuti H, Rakhmat II, Handayani DR. Prinsip Dasar Pemeriksaan Radikal Bebas dan Antioksidan. 2018. Deepublish Publisher. Yogyakarta.

7. Ashokumar T. Antioxidants: New-generation Therapeutic Base For Treatment of Polygenic disorders. Current Science. 2015; 86(8), 1092 1102

8. Reynertson KA. Phytochemical Analysis of Bioactive Constituens from Edible Myrtaceae Fruit. Dissertation, The City University of New York; 2015.
9. Kumalaningsih S. Antioksidan Alami, Penangkal Radikal Bebas, Sumber Manfaat dan Cara Penyediaan dan Pengolahan. Surabaya: Trubus Agrisarana; 2006

10. Herni KR, \& Shofia AZ. Skrining Fitokimia dan Penentapan Kadar Senyawa Fenolik Total Ekstrak Rimpang Lengkuas Merah dan Rimpang Lengkuas Putua (Alpini galanga L.). Sekolah Tinggi Ilmu Farmasi. Bandung, 2015; 1(1), 295-302

11. Wathoni N, Rusdiana T, Hutagaol RY.Formulasi Gel Antioksidan Ekstrak Rimpang Lengkuas (Alpinia galanga L.Wild) Dengan Menggunakan Basis Aqupec 505 HV. Fakultas Farmasi Padjajaran. 2009; 7:15-27

12. Herborne JB. Metode Fitokima. Edisi Kedua. Padmawinata K, Soediro I, Penerjemah Bandung : ITB. Terjemahan dari Phytochemical methods; 1987

13. Fu L, Xu BT, Gan RY, Zhang Y, Xu XR, Xia EQ, Li H. Total Phenolic Contents and Antioxidant Capacities of Herbal and Tea Infusion, Int. J.Mol. Sci. 2011; 12. 2112-2124

14. Prakash A, Rigelhof \& Miller E. Antioxidant Activity. JournL Analytical Chemistry. medallion laboratorius. Analitycal Progess. 2001; Vol 10,No. 2.

15. Ujala, Inaocha, \& Joylani S. Essential Oil Content and Antioxidant Activity of Methanolic Rhizome Extract Of Two Zingiberace Plants In The Hill Of Manipur. Institutional Biotech Hub, Department of Botany, Presidency College, Motbung, Manipur; 2018.

16. Kasertsart J. Antioxidant Activities and Antioxidative Components in Extracts of Alpinia galanga (L.) Sw. Department of Food Science and Technology, Faculty of Agro-Industry, Kasetsart University, Bangkok 10900, Thailand; 2009.

17. Azkiyah RD, dan Tohari. Pengaruh Ketinggian Tempat terhadap Pertumbuhan, Hasil dan Kandungan Steviol Glikosida pada Tanaman Stevia (Stevia rebaudiana). Departemen Budidaya Pertanian, Fakultas Pertanian, Universitas Gadjah Mada. 2019; 8(1), 1-12

18. Astuti E, Retno S, Umar AJ, Sofia M, \& Sismindari. Pengaruh Lokasi Tumbuh, Umur Tanaman dan Variasi Jenis Dstilasi Terhadap Komposisi Senyawa Minyak Atsiri Rimpang Curcuma mangga Produksi Beberapa Sentra di Yogyakarta. Program Dektoral Program Studi Bioteknoligi. Universitas Gadjah Mada. 2014; 21(3), 323-330 